\title{
Self-image, perception of peers' risk acceptance and risky shift*
}

\author{
HELMUT LAMM \\ GISELA TRONMSDORFF \\ EDITH ROST-SCHAUDE \\ University of Mannheim
}

Abstract

Twelve four-person female groups of subjects displaying the typical underestimation of their peers' (relative to their own) risk acceptance were compared with twelve groups of subjects who (slightly) overestimated their peers' risk acceptance. Risk level was measured by responses to a set of hypothetical decision situations known to elicit risky shift on the basis of previous research. Risky shift following group discussion was not found to be different for the t' , types of groups, casting doubt on the widely suggested role of peer underestimaiion in risky shift. Nor was risky shift affected by whether or not group members stated their individual decisions publicly at the close of discussion. Larger group risky shifts were accompanied by higher self-ratings given by group members on a number of polarity scales. In discussing the findings, we outline an explanation of group-induced shifts in risk taking, emphasizing the motivational and informational inducements provided by group discussion whereby group members come to discard their prior positions in favor of more aspired ones.

The weight of relevant research indicates that the group risky shift is caused by the operation, through discussion, of a pre-existing bias toward risk acceptance. The characteristics of this 'value', and how it operates, remain controversial questions, and the present study is intended to provide some clarification.

Various types of evidence have been submitted to show that risk acceptance is

* Conducted at the Sonderforschungsbereich für Sozial- und Wirtschaftspsychologische Entscheidungsforschung, Universität Mannheim, with financial aid from the Deutsche Forschungsgemeinschait. We thank Wiltrand Paule for assisting in running subjects and Jörg Graff for his belp in the computer analysis of the data. Dr. Paul Gebh:ird and Jörg Graff authored the computer programs used. 
valued considering those hypothetical decision situations (Choice-Dilemma problems) (Kogan and Wallach, 1964) on which risky shift occurs. And each of these indicators of a risk value is at the basis of a corresponding explanation of the risky shift, each of them constituting a version of 'value theory'.

1. Madaras and Bem (1968) have shown that risk-accepting stimulus persons are more positively evaluated than cautious stimulus persons. Similarly, Jellison and Riskind (1970) have shown that higher risk levels chosen by (or ascribed to) a stimulus person are associated with higher abilities being attributed to him by subjects. According to the explanation of the risky shift proposed by the latter authors, the group situation increases the typical participant's motivation to appear as a person of high ability, leading him to come out for riskier decisions at the end of the discussion. No empirical evidence exists as yet on this version of value theory, that is, on an association between value (thus operationalized) and risky shift.

2. Levinger and Schneider (1969) and Lamm, Schaude, and Trommsdorf (1971) have shown that college students place the ideal (most admired and respected) decisions at higher risk levels than their actual decisions, a fact which these authors consider as an indication of an 'unfulfilled' value of risk. The corresponding explanation of the risky shift proposes that there is something about the group interaction (discussion) that allows the typical participant to move toward the (riskier) decisions he considers ideal. Lamm, Schaude and Trommsdorff (1971) have shown that risky shift is indeed an empirical function of the extent to which group members value risk acceptance (as defined above).

3. Substantiating an earlier claim by Hinds (1962) (see Brown, 1965), Wallach and Wing (1968) and others have shown that college students typically think that their peers are less willing to accept risk than they are themselves, from which these authors infer that 'risk is a value' (Wallach and Wing, 1968). Th: corresponding explanation of risky shift is as follows. During the group interaction (discussion), the typical participant discovers that the others are just as risk-accepting as he himself; in order to keep up his image as a risk-taker, he shifts toward riskier decisions. Clark, Crockett, and Archer (1971) found more risky shift with groups of subjects strongly underestimating their peers' risk acceptance (as described above), as compared to groups of overestimating subjects.

The esent study is intended to investigate critically the nature of the last type of value index (underestimation of peers' risk acceptance) and its role in the risky shift.

Why should subjects typically consider themselves as xcelling their peers in risk acceptance? a) One possible reason is that this allow's them to see (and/or 
portray) themselves (to the researcher) as superior. But note that this already assumes that these subjects regard the willingness to take risks as a valuable characteristic to have (and/or display). The truth of that assumption would still have to be tested, independently. Secondly, it assumes a fair level of self-esteem, and/or a desire $t \cap$ be esteemed (by the researcher who gets to see the subject's answers). b) Another possible reason is that subjects, while themselves considering high risk acceptance as ideal, believe that their peers' ideals are at comparatively lower risk levels, hence ascribing less risky actual decisions to their peers. c) Another conceivable reason for the relatively rishy self-image of the typical subject is that he may feel that he would be unusually able, try unusually hard, and/or be unusually lucky, meaning that he would be more favored than bis peers with a positive (successful) outcome. However, this possibility is hard to investigate with, and indeed not applicable to, the hypothetical decision-making situations (K)gan and Wallach's Choice Dilemmas) used in all relevant studies mentioned above (including the present study). But they could be fruitfully investigated using decision tasks with actual outcomes and clearly separable skill and chance components.

Value indicator or not, the fact that subjects typically think of themselves as more risk-prone than their peers may underlie, or contribute to, the risky shift. The findings of Clark, Crockett and Archer (1971) already mentioned seem to point to such a conclusion. However, as these authors note themselves, along with the variation of their independent variable went a variation in another variable: the underestimator groups, compared with the overestimators, were higher risk-takers. Thus, the higher risky shift of the underestimators could be due to their higher initial risk levels. That interpretation is quite plausible, considering that Lamm, Schaude, and Trommsdorff (1971) found subjects' actual and ideal initial positions to be positively correlated, and also found that groups with riskier ideal decisions (but equal actual decisions) showed more risky shift than groups with more cautious ideals. The present study, in which, too, one independent variable is the extent (or presence/absence) of underestimation, will use an analysis of covariance to extract the possible confounding effects of actual and of ideal initial decisions.

Another purpose of the present study is to explore the motivational basis of the risky shift. Each of the explanatory formulations (versions of value theory) noted above involves the (unfulfilled) desire to excel, that is, to affirm risk levels that 1. indicate high ability, 2. are considered ideal by oneself, or 3. surpass those of one's peers. The group discussion presumably provides the occasion to revise one's earlier decisions so as to move toward, or maintain, one's standard of excellence. The question of interest here is whether the psychological reward (sou ht) for the 
manifestation of superior behavior is approval by oneself or approval by others. ${ }^{1}$ In other words, does risky shift primarily serve the need for self-esteem or the need of social esteem.

Out own previous research (Lamm, Schaude and Trommsdorff, 1971) has yielded some rather inconclusive findings on that question. Dyads composed of subjects high, as compared with those low, in 'need for social approval' (Crowne and Marlowe, 1964) did not differ with regard to risky shift. But this may have been due to the small group size: one other participant (the case of the dyad) presents less incentive than (say) three others (the case of the four-man group) for displaying a socially approved image. Also, the Crowne-Marlowe questionnaire contains a dimension of self- as well as social approval (Crowne and Marlowe, 1964 , p. 201). More informative was a near significant correlation $(p<.10)$ between the dyadic subjects' joint self-esteem scores (Cohen, 1953) and their risky shift. As the self-esteem questionnaire was administered after the discussions, the direction of causality was left open.

To investigate the possible role of self-esteem, a test-retest design will be used in which the subjects indicate their self-esteem before and after group discussion. Any enhancement in self-esteem following group discussion, or a correlation between initial self-esteem and risky shift or between risky shift and self-esteem enhancement, will provide pertinent clarifications.

To investigate the possibic role of social esteem (respect from others), the present experiment involves one condition in which the decisions at the end of the group discussion (without a consensus requirement) are stated publicly and another one in which they are noted down privately by the participants. If the desire for social esteem is involved, more risky shift may be expected in the public condition, since it provides more of a basis for the (actual or imagined) approval presumably forthcoming from the others (participants and/or experimenter) for respectably risky decisions.

In sum, the present study is intended to provide evidence on a) the psychological basis, and contribution to risky shift, of subjects' tendency to view their peers as less risky than themsel:es, and b) the roles played by self- and by social esteem motivation in the risky s!ift.

1. Of course, performing at high stindards of excellence can be its own reward, arising from something like the chievement motive (see Heckbausen, $19 n: ?$ But it appears impl: isible to make sut. an assumption here, given the present concern with hypothetical decision situations (the ChoiceDilemmas used in the research here discussed) where no actual performance tskes place. 


\section{Method}

\section{Subjects}

One hundred and forty-six female German bigh-school students (ages 15-20) volunteered to participate in return for a honorary of 10 Deutsche Mark. On the basis of initial measures and availability, 114 of the 146 participants in the initial session were selected for the experiment proper.

\section{Risk-taking instrument}

Tue Choice-Dilemmas task (Kogan and Wallach, 1964, App. E) was used to measure risk taking. Items 6 and 12 were omitted, and the remaining items were translated and adapted to fit the German cultural context (see Lamm and Kogan, 1970). Each item presents a hypothetical decision situation as might occur in every-day life, in which a protagonist has to choose between a relatively unattractive but safe course of action and a more attractive but risky alternative (for example, carrying on with a heart ailment versus undergoing an operation). The level of risk-taking is indicated by the minimum odds of success considered necessary for choosing the risky alternative. The 10-point risk-taking scale ranges from a $10 \%$ to a $100 \%$ chance that the risky alte:native would be successful.

\section{Initial (pre-treatment) session}

Between 10 and 30 subjects took part in any particular initial session; all assignments were to be carried out individually.

\section{Choice-Dilemma measures}

In the first part of the session, $S \mathrm{~s}$ went through the ten-itern Choice-Dilemma instrument four times.

a) For each item, they indicated the minimum odds they considered necessary before recommending the choice of the risky alternative.

b) They were then asked to go through the Choice-Dilemmas again and indicate, for each item, the response they thought would be given by the majority of G' man students of their own sex. I: ither' words, they nord down the minimum odds of success presumably chosen by most of their peers.

c) Then they were asked to go through the items another time and indicate the decisions for which they had the inghest regard ('... Thre höchste Anerkennung finden würde"). 
d) As a final assignment, they indicated the decisions for which they thought their peers bad the highest regard.

\section{Polarity ratings}

In the second part of the initial session, the subjects were asked to rate themselves on thirteen seven-point semantic-differential scales representing the dimensions of evaluation, activity, and potency (Osgood and Tannenbaum, 1957). The instrument was used in the (translated) version developed by Pervin and Lilly (1967) for their study of seif-esteem. Instructions stressed that subjects should indicate their present impressions, and were not expected to note down judgements of lasting truth.

The subjects were asked to indicate a) how they saw themselves, b) how they thought they were seen by their peers, c) how they wanted to be (their ideal self), and d) how they wanted to be seen by their peers. The thirteen polar adjective pairs were as follows: sociable-unsociable, good-bad, passive-active, eager-indifferent, strong-weak, constrained-free, cruel-kind, selfish-unselfish, slow-quick, excitable-calm, severe-lenient, soft-hard, wise-foolish. (The good, active, or potent pole of each dimension is given in italics.) Subjects completed all thirteen ratings on question a), then on b), etc.

\section{Experimental (treatment) session}

Group condition (24 four-person groups)

The group discussion took place a few weeks ifter the initial session. Upon arrival at the laboratory, each subject received an instruction sheet and a booklet containing the Choice-Dilemma descriptions.

The four participants were instructed to discuss each of the problems and, at the end of a discussion, indicate their decisions (minimum odds of success considered necessary for choosing the risky alternative). For the latter, they could draw on the considerations brought out during the discussion. It was pointed out that while each member should make her own decision, the exchange of views could, of course, lead to a consensus; the latter was, however, not required.

The group was asked to discuss each item thoroughly before making their decisions but to take no more than five minutes for each item. The decisions were to be noted down by each subject herself (private condition); or to be announced aloud for the experimenter to note them down, in rotating order over the ten items (public condition).

After all Choice-Dilemma items had been discussed, the subjects were asked to do the polarity ratings again (see 'initial session'). 


\section{Control condition (18 Ss)}

This was essentially a retest - without intervening group discussion - taking place a few weeks after the initial session. The subjects, several at a time, indicated their own decisions on the Choice Dilemmas and made the polarity ratings described above.

\section{Independent variables and design}

Factor A: Underestimation of peer's risk acceptance

This variable concerned whether the subjects showed little of the typical underestimation of peers' risk acceptance or slight overestimation, or whether they showed it to a marked degree. Underestimation was measured by the difference between a subject's estimate of her peers' decisions and her own decisions on the ChoiceDilemmas (that is, measure b) minus measure a), as described above). On the basis of this index, the 146 subjects of the initial sample were classified, by median split, as low or high in underestimation.

As underestimation correlated negatively with the value placed on riskiness (measure a) minus c) as described above) $(r=-.22, d f=144, p<.05)$, and since - as shown previously (Lamm, Schaude and Trommsdorff, 1971) - higher value results in more risky shift, value had to be kept constant over the two underestimation conditions. Aside from this selection criterion, subjects were assigned at random to the two conditions. However, it proved impossible to equalize them also with regard to subjects' own initial decisions. Hence, the control of the latter variable had to be left to covariance analysis.

\section{Factor B: Statement of final decisions}

The second independent variable concerned whether the group members put down their final decisions (after group discussion) privately or announced them publicly. Groups were assigned at random to these two conditions.

The design for the group sample thus was a $2 \times 2$ factorial with 6 groups in each cell

From the remainder of the initial sample (after assignment to experimental conditions) subjects were assigned to the control condition $(N=18)$ at random and on the basis of their availability at the scheduled time. The control sample could not be inclided into an overall design because it was too small and because, for practic:il reasons, it proved impossible to introduce the experimental inanipulations here. The main reason for including a control sample was to check for any retest effects on the Choice-Dilemma decisions and on the polarity ratings. 


\section{Results}

Measures obtained from the initial sample

Table 1. Means for initial Choice-Dilemma measures and polarity ratings

\begin{tabular}{|c|c|c|c|c|c|}
\hline under & $\begin{array}{l}\text { Low } \\
\text { estimation }\end{array}$ & under & $\begin{array}{l}\text { figh } \\
\text { estimation }\end{array}$ & \multirow[t]{2}{*}{ Control } & \multirow[t]{2}{*}{$\begin{array}{l}\text { Initial } \\
\text { Sanple }\end{array}$} \\
\hline Public & Private & Public & Private & & \\
\hline$N=24$ & $N=24$ & $N=24$ & $N=24$ & $N=18$ & $N=146$ \\
\hline
\end{tabular}

Choice Dilemmas a
(a) Own decisions
62.04
59.17
51.00
50.33
54.89
55.15
(b) Peer decisions
57.92
55.46
66.13
67.58
58.44
60.97
47.33
46.33
37.42
38.42
43.44
42.32
(d) Peers' ideal decisons
46.42
-4.12
45.17
47.08
50.75
50.61
47.22
(e) Underestimation (b minus a)
$14.71 * *$
-3.71 *
$15.13 * * \quad 17.25 * *$
3.55
$5.82 * *$
(f) Value (a minus c)
$12.84^{* *}$
$13.58^{* *}$
$11.91 * *$
$11.45^{* *}$
$12.83 * *$
11.50 *
10.29 *
$19.05 * *$
$16.83 * *$
7.83 *
$13.75 * *$

Polarity ratings $\mathrm{b}$

\begin{tabular}{|c|c|c|c|c|c|c|c|}
\hline (b) & Actual self & 44.58 & 46.04 & 44.04 & 42.38 & 46.72 & 45.02 \\
\hline (i) & Peers' image of self & 44.62 & 45.96 & 42.71 & 42.29 & 45.83 & 44.40 \\
\hline (j) & Ideal self & 33.92 & 35.58 & 35.25 & 35.46 & 35.72 & 35.39 \\
\hline (k) & Ideal peers' image & 37.54 & 38.63 & 37.13 & 38.67 & 38.39 & 38.11 \\
\hline
\end{tabular}
the evaluation, activity, or potency dimensions. Scores are the sum over the thirteen seven-point scales.

Table 1 shows the means for the Choice-Dilemma responses and polarity ratings. Considering the initial sample of 146 subjects, there is a significant underestimation of peers' risk acceptance $(p<.001)$, and there is a significant risk value (ideal decisions are at higher risk levels than actual decisions) $(p<.001)$. The findings from our earlier study (Lamm, Schaude and Trommsdorff, 1971) based on female university students, are thus replicated with female high-school students. In addition, as the table shows, subjects attribute a risk value (discrepancy) of equal magnitude as their own to their peers $(p<.001)$. In this sense one is justified in speaking of a srial value. However, it may further be noted that subjects place their peers' idcals at significantly lower risk levels than their own ideals on the Choice-Dilemma scale $(p<.05)$.

The patten of correlations among the various masures mentioned :bove paral- 
leled the findings of Lamm, Schaude and Trommsdorff (1971) and therefore will not be described further.

Statistics on the polurity ratings obtained from the initial sample are not pr:sented in this report, since they are of no relevance to the present purposes. None of the correlation coefficients among Choice-Dilemma and polarity-rating measures were significant.

\section{Shifts (changes from first to second measure)}

\section{Choice-Dilemma decisions}

Table 2 presents the shifts in risk taking for the various conditions. In the 24 experimental groups, there was a significant shift toward higher risk levels ( $t=$ $6.20, d f=23, p<.001$ ), whereas $\mathrm{Ss}$ in the control condition did not shift significantly. An analysis of variance yielded no significant effects of either independent variable; ${ }^{2}$ nor did analysis of covariance using own initial decisions, ideal decisions, and peers' ideal decisions as covariates.

Table 3 presents an analysis of cases in which relatively 'pure' conditions of overestimation and of underestimating of peers' risk acceptance were given. Among the 240 discussion cases ( 24 groups, each discussing 10 items) we picked out those in which no member had underestimated his peers' risk acceptance (in other words, cases in which every group member had thought his peers' decisions were more risky, or equal, relative to his own decisions); there were 30 such cases of (what we will call) overestimation (or low underestimation). In addition, we picked out those cases which no member had overestimated his peers' risk acceptance (in other words, cases in which every group member had thought his peers' decisions were less risky, or equal, relative to his own decisions); there were 26 such cases of (high) underestimation. (It should be noted that, unavoidably, the various items and groups are represented with different frequencies in this post-hoc collection of 'pure' cases.) ${ }^{3}$ There was no difierence in mean amount of risky shift among these two conditions. The same negative result was found when the underestimation cases were selected in such a way as to keep initial risk level constant over the two conditions (but - unavoidably - relaxing the criterion of underestimation so that one or more group members could be an overestimator in a particular case).

2. The $F$ values for the effects of underestimation and decision statement and their interaction were $.11,1.37$, and .48 , respectively.
3. The same type of procedure has been used by Vinokur (1970) in his post-hoc analysis of the effect of initial position distribution on risky shift. 
Table 2. Means and standard deviations for risky shift

\begin{tabular}{|c|c|c|c|c|c|c|c|c|}
\hline \multicolumn{3}{|c|}{ Low underestimation } & \multicolumn{3}{|c|}{ High underestimation } & \multirow{2}{*}{$\begin{array}{l}\text { Whole } \\
\text { Sample b }\end{array}$} & \multicolumn{2}{|c|}{ Control } \\
\hline Public & Private & & Public & Priva & & & & \\
\hline $\bar{X} \quad S D$ & $\bar{X}$ & $S D$ & $\bar{X} \quad S D$ & $\bar{X}$ & $S D$ & $\bar{X} S D$ & $\bar{X}$ & $S D$ \\
\hline $11.46 * 5.08$ & $9.83 *$ & 8.12 & $12.41 * 5.22$ & 6.38 & 10.62 & $10.09 * 7.97$ & 2.39 & 10.71 \\
\hline
\end{tabular}
group scores (four members average).

Table 3. Post-hoc analysis of pure cases

\begin{tabular}{lcccccc}
\hline & $\begin{array}{c}\text { Overestimation } \\
(N=30)\end{array}$ & \multicolumn{2}{c}{$\begin{array}{c}\text { Underestimation } \\
(N=26)\end{array}$} & \multicolumn{2}{c}{$\begin{array}{c}\text { Underestimation 2a } \\
(N=30)\end{array}$} \\
\cline { 2 - 7 } & $\bar{X}$ & $S D$ & $\bar{X}$ & $S D$ & $\bar{X}$ & $S D$ \\
\hline Own initial decisions & 6.74 & 1.04 & 4.10 & 1.15 & 6.38 & 1.14 \\
Underestimation & $-1.07^{* *}$ & .67 & $2.71^{* *}$ & .88 & $.92^{* *}$ & .58 \\
Risky shift & $1.41^{* *}$ & 1.95 & $.78^{*}$ & 1.29 & $1.64^{* *}$ & 2.12 \\
\hline
\end{tabular}

N.B.: Of the 240 discussion cases (24 groups, each discussing 10 items), those were picked out on which the criterion of prevalent overestimation or underestimation of peers' risk acceptance was fulfilled (see text). a Matching the overestimation condition with regard to own initial positions, but relaxing the criterion regarding underestimation (see text).

* $p<.01$.

** $p<.001$ (two-tailed $t$ tests for correlated samples).

\section{Polarity ratings}

No significant changes were found from the first to the second measure on the polarity ratings. The picture was the same for the control and the four experimental conditions, showing no effect of group discussion or of the independent variables.

\section{Correlations with risky shift}

Correlations among the Choice-Dilemma measures and risky shift displayed the same pattern as in Lamm, Schaude and Trommsdorff (1971) and will not be taken up isere.

The second (post-discussion) polarity ratings (summed over the thirteen scales) of actual self, peers' image of self, ideal self, and peers' ideal image were significantly or near-significantly correlated with risky shift across all 24 groups $(r=$ 
$-.46,-.36,-.44$, and -.43 , respectively - coefficients above .40 being significant at the .05 level, with $22 \mathrm{df}$ ). ${ }^{4}$ In other words, greater risky shift went along with higher self-regard. The polarity measures mentioned above correlated positively among each other. It is emphasized that all these correlations involved group scores. For individual scores, the above correiations were in the same direction but not significant.

\section{Discussion}

Interpreting the underestimation of peers' risk acceptance

As our data show, the discrepancy - in the subjects' eyes - between their peers' actual and ideal decisions is no larger than between their own actual and ideal decisions. Hence, the underestimation of peers' risk acceptance cannot be due to the fact that subjects believe their peers to live less up to their risky ideals than themselves. (However, the reverse direction of causality may also be true. This question can be answered only by appropriate variations in the sequence of various judgments made by the subjects.) It may also be noted that subjects' own actual decisions are significantly less risky than their peers' ideal decisions. In other words, they acknowledge that their own actual decisions are at levels of risk below what their peers would consider most admirable.

\section{The role of underestimation in risky shift}

The evidence from the study of Clark, Crockett and Archer (1971) - that (greater) underestimation of peers' acceptance causes (greater) risky shift - could not be reproduced here. No differences in risky shift were found between groups with (slight) overestimation and gxoups with (considerable) underestimation of peers' risk acceptance, even after differences in initial own risk decisions were controlled by analysis of covariance.

It must be acknowledged that Clark et al.'s (1971) procedure for testing the effect of estimation of peers' decisions was more sensitive, by their criterion for manipulating that variable. Their four overestimation ('cautious') groups were defined as groups whose members believed their peers to be more risky than them-

4. Considering the three subsets (evaluation, activity, potency) separately, significant correlations with risky shift were found only for the activity subset in the case of ratings of actual self $(r=-.54)$ and for the potency subset in the case of ratings of peers' ireal image $(r=-.48)$. 
selves on at least four of the six items used; their six underestimation ('risky') groups consisted of subjects who believed, on at least four items, that their peers were less risky, or (at most) as risky, relative to themselves. In other words, overestimation (or, respectively, underestimation) was present in (at least) 67 percent of the items. We computed the same index and found overestimation to be present in only 43 percent of the cases in our low-underestimation condition, whereas underestimation (as defined above) was present in 84 percent of the cases in the high-underestimation condition. Thus there is reason to assume that our low condition was not as 'pure' as that of Clark et al. (1971).

In view of the above, we selected, post hoc, relatively 'pure' cases of overestimation and underestimation (Table 3). No differences in risky shift were found when cases were selected so that initial decisions were equal over the two conditions but where, unavoidably, the underestimation cases were somewhat less pure, allowing the presence of one or more overestimators per case in that condition ('underestimation 2'). When underestimation cases were selected with priority for 'pureness' - but with higher initial risk levels, compared with the overestimation cases - risky shift was, again, not different in the two conditions. Thus, the findings of Clark, Crockett and Archer (1971) were in no way replicated.

The puzzling problem remains to explain the results of Clark, Crockett and Archer (1971), who did find the estimation factor to have an effect. Consider the following interpretation. For their overestimation condition ('cautious' subjects) Clark et al. (1971) assembled groups of fairly cantious initial risk levels, averaging 7.17 per item, whereas our subjects in this condition averaged only 6.06 per item (5.43 and 5.07 are the respective values in the (high) underestimation condition in the two studies). Now, the average sizes of risky shifts in the low (or overestimation) and high (underestimation) conditions are 1.07 and .95 in our study and .23 and .99 in theirs, suggesting that it is the absence of risky shift in Clark et al.'s (1971) overestimation condition that needs to be explained. We suggest that in these groups the leaning toward caution was sufficiently strong to induce further movement toward the cautious pole, by the kind of extremization (or 'polarization') reported in recent studies (Moscovici and Zavalloni, 1970; Doise, 1969, 1970; Fraser, Gouge and Billing, 1971). The forces normally leading to risky shift were thus offset by forces leading in the opposite (cautious) direction, the net result being no shift at all.

The contribution of the present findings will be further clarified by reference to the trid of Lamm, Schaude and Trommsdorff (1971). The latter compared low with high-value dyads ('value' being defined as the distance of subjects' actual decisions from their more risky ideal decisions). The same group-compositional "'ocedure was used as in the present study. Now, the manipulated differences 
between the two value conditions of the earlier study was 14.11, that is, even somewhat smaller than the manipulated difference - 20.09 - between the two underestimation conditions of the present study. Yet, whereas the former study yielded a significant risky-shift difference between its two conditions, the present study yielded no difference whatever. The conclusion is that - by our procedure value (as we operationalize it) contributes more to risky shift than does the underestimation factor. This is a conservative statement. We do not consider it warranted by our findings to conclude that the role of underestimation in risky shift is negligible; our kind of manipulation may have been inadequate. On the other hand, it can be concluded fro mour data that, for risky shift to occur, it is not necessary that the majority of group members initially believe their peers to be less risky than themselves.

\section{Implications of other results}

Our data indicate that risky shift is not affected by whether the final decisions are stated publicly or left undisclosed. It must be noted, however, that our private/ public manipulation cannot be considered a very strong one, since subjects presumably disclose their positions to a large extent during the discussion in either condition.

The fact that in the high underestimation groups risky shift was twice as large in the public than in the private condition (12.71 versus 6.38) can at best be considered suggestive, since it is not a significant difference $(t=1.19, d f=10)$. The size of the difference, and the fact that it occurred among high underestimators - who are presumably more sensitive to the disclosure of positions - does lend some interest to it.

Overall, self-ratings did not become more positive, active, or potent, following group discussion and risky shift. (Again, our measurement technique may have been insensitive.) On the other hand, considering group scores, we did find that subjects' risky shift correlated positively with the self-ratings they gave immediately after the discussion session. These correlations - which were not due to any correlations between initial Choice-Dilemma measures and polarity ratings - indicate that, the more a group of subjects had moved toward higher risk, the higher they rated themselves on evaluation, activity, and potency. ${ }^{5}$ This motivational accompaniment of risky shift is plausible if one considers that through risky shift

5. We think it is justified in this discussion to focus exclusively on the first set of 13 ratings - concurning bow subjects see their actual self - and ignore the three subsequent ones (ideal self etc.), which were obviously not independent of th: first. 
individuals move closer toward realizing ideal, active, and potent levels of conduct. That high risk levels are regarded as implying greater activity and potency (in addition to value) has been shown by Madaras and Bem (1968) and by Jellison and Riskind (1970) in studies limited to perceptual and rating measures at the individuai level, without group interaction. The present study is the first to demonstrate an empirical link between subjects' shift to higher risk levels and their impressions of themselves on the dimensions of evaluation, activity, and potency. It may be recalled that in a previous study the present authors found a correlation between risky shift and self esteem (discrepancy between image of actual and of ideal selfi) as measured after the group discussions (Lamm, Schaude and Trommsdorff, 1971). That earlier resuit can now be considered as having been substantiated by the evidence from the present study. The two findings - and the differences between them (a discrepancy measure in the earlier study, a simple image measure in the present one) - point to the need for more direct investigation of the relationship between changes in risk taking and self-image/esteem.

\section{Gineral implications}

What are the implications of our findings for a general unified explanation of risky shift in Choice-Dilemma decision situations? The main conclusion suggested by the data described above is that the underestimation of peers' risk acceptance plays no role in risky shift. "The acceptability of that conclusion depends on whether there is a plausible theory which can do without the proposition that underestimation causes, or contributes to, risky shift.

Instead of recapitulation of available risky-shift theories and their various versions (see Pruitt, 1971, for the most recent review and pertinent references), we will outline what we consider - on the basis of the existing research (including the present findings) as well as speculation - as the most plausible explanation of the phenomenon.

The fact that subjects place the ideal ('most admirable') decisions at higher risk levels, relative to their own actual decisions, indicates that they would readily commit themselves to higher risk levels if they had sufficient inducement and justification for doing so. Now, the inducement provided by the group (discussion) situation may be of two kinds.

First, the presence of others (group members and experimenter) offers greater incentive, relative to the prior solitary situation, for embracing (more) admirable positions. In other words, the need for respect from others as well as for selfrespect becomes more strongly activated when others are present. But a subject must have some 'objective' justification (almost in the sense of a pretext) - there 
must be some intervening occasion - for discarding his prior position. Such a justification is offeren by the fact of group discussion. This explanation, then, would hold even if the discussion simply reflected the distribution of group members' prior positions, in so far as the mere occurrence of group discussion makes it appear admissible (in terms of the implicit rules of an experiment) fo: the subjects to change their prior positions.

However, there is reason to assume that the discussion content itself - independent of the initial distribution of positions - is biased in favor of higher risk taking (relative to the average prior position), constituting a second inducement: We propose that the ypical participant in the discussion selects for his (initial) arguments those that speak in favor of his aspired position (that is, to pursue the desired goal even at a lower chance of success than he originally considered as barely tolerabie). He does so in order to 'test' whether - by the socinl reality constituted by the group - the more aspired, risky position might be considered acceptable. Thus, the ensemble of discussion arguments come to be more in favor of risk acceptance than the arguments originally considered by each participant. As an ancillary inducement, going also in the direction of higher risk, the typical subject may have a tendency to be consistent with himself over a series of discussion contributions, constituting a sort of 'lock-in' for the higher risk bias of arguments described above.

We suspect that both of the social inducements described above are operative in the typical risky-shift situation. Determining their relative weights would be a matter of empirical research.

But what about those (few) Choice-Dilemma items on which no risky shift, or even cautious shift, has been reported to occur (Rabow, Fowler, Bradford, Hofeller and Shibuya, 1966; Stoner, 1968; Vidmar and Burdeney, 1969; Fraser, Gouge and Billig, 1971)? Our assumption is that on such items subjects consider the most admirable decisions to be no higher, or even lower, in risk level than their own actual decisions. Thus, no motivational pull comes from higher risk levels, or it may even come from lower risk levels.

The primary question then becomes, on what does it depend whether (in the subjects' eyes) the ideal ('most admirable') decision is more risky, equal, or less risky, relative to their own actual decisions. We submit that higher risk levels are considered ideal only if the goal is worth pursuing, that is, if the attractiveness of the positive outcome (the case of success) of the risky course of action outweighs the aversiveness of its negative outcome (the case of failure) and also exceeds the outcome value of the safe course of action. In other words, whether higher risk acceptance is 'valued' - whether it has a motivational pull - depends on the relative size and configuration of the utilities of the possible outcomes involved. Thus, 
according to this view, parameters invoked in behavioral decision theory (see Becker and McClintock, 1967) enter as important determinants of choice shift, which is supported by recent evidence from Burnstein et al. (1971) and Vinokur (1971).

\section{REFERENCES}

Becker, G. M., and McClintock, G. G. (1967) Value: Behavioral decision theory. Ann. R. Psychol. 18, 239-286.

Brown, R. (1965) Social psychology, New York, Free Press.

Burnstein, E., Miller, H., Vinokur, A., Katz, S., and Crowley, J. (1971) Risky shift is eminently rational. $J$. Pers. soc. Psychol. 20, 462-471.

Clark, R. D., III, Crockett, W. H., and Archer, R. L. (1971) Risk-as-value bypothesis: The relationship between perception of self, others, and the risky shift. J. Pers. soc. Psychol. 20, 425-429.

Cohen, A. K. (1953) The effects of situational structure and individual selfesteem on threat-oriented reactions to power. Unpublished doctoral dissertation, University of Michigan.

Crowne, D. R., and Marlowe, D. (1964) The approval motive: Studies in evaluative dependence. New York, Wiley.

Doise, W. (1969) Jugement collectif et prise de risque des petits groupes. Psychol. franc. 14, 87-95.

Doise, W. (1969) Intergroup relations and polarization of individual and collective judgments. J. Pers. soc. Psychol. 12, 136-143.

Fraser, C., Gouge, C., and Billig, M. (1971) Risky shifts, cautious shifts, and group polarization. Euron'. J. soc. Psychal. 1, 7-30.

Heckhausen, $\mathrm{H}$. (1967) The anatomy of achievement motivation. New York, Academic Press.

Hinds, W. C., Jr. (1962) Individual and group decisions in gambling situations.
Unpublished Master's Thesis, School of Industrial Management, M.I.T.

Jellison, J. M., and Riskind, J. (1970) A social comparison of abilities interpretation of risk-taking behavior. J. Pers. soc. Psychol. 15, 375-390.

Kogan, N., and Wallach, M. A. (1964) Risk taking: A study in cognition and personality. New York, Holt.

Lamm, H., and Kogan, N. (1970) Risk taking in the context of intergroup negotiation. J. exp. soc. Psychol. 5, 351-363.

Lamm, H., Schaude, E., and Trommsdorff, G. (1971) Risky shift as a function of group members' value of risk and need for approval. J. Pers. soc. Psychol. 20, 430-435.

Levinger, G., and Schneider, J. (1969) Test of the 'risk is a value' hypothesis. J. Pers. soc. Psychol. 11, 165-169.

Madaras, G. R., and Bem, D. J. (1968) Risk and conservatism in group decisionmaking. j. exp. soc. Psychol. 4, 350365.

Moscovici, S., and Zavalloni, M. (1969) The group as a polarizer of attitudes. J. Pers. soc. Psychol. 12, 125-135.

Osgood, C. E., Suci, G. J., and Tannenbaum, P. H. (1957) The measurement of meaning. Urbana, Ill., University of Illinois Press.

Pervin, L. A. and Lilly, R. S. (1967) Social desirability and self-ideal self ratings on the semantic differential. Educ. psychol. Messmt. 27, 845-853.

Pruitt. D. G. (1971) Choice shifts in group (i) cussion: An introductory review. 
J. Pers. soc. Psychol. 20, 339-360.

Rabow, I., Fowler, F. J., Jr., Bradford, D. L., Hofeller, M. A., and Shibuya, M. (1966) The role of social norms and leadership in risk-taking. Sociometry $29,16-27$.

Stoner, F. (1968) Risky and cauti.its shifts in group decisions: The influence of widely held values. J. exp. soc. Psychol. $4,442-459$.

Vicmar, N., and Burdeney, T. C. (1969) Interaction effects of group size and relative risk position with item type in the 'group risky shift' effect. Depart-

\section{Résumée}

Douze groupes de sujets de quatre personnes appartenant au sexe féminin affichant la sous-estimation typique de l'acceptation du risque chez leurs pairs (par rapport à la leur) ont été comparés à douze groupes de sujets qqui surestimaient (légèrement) l'acceptation du risque chez leurs pairs. Le niveau du risque a été mesuré moyennant les réponses apportées à une série de situations hypothétiques de décision connues pour inciter à la prise de risque sur la base d'une recherche préalable. On a trouvé que la prise de risque émanant de la discussion du groupe n'était pas différente dans les deux types de groupe, projetant un doute sur le rôle largement suggéré de la sous-estimation du pair concernant la prise de risque. La prise de risque n'a pas davantage été affectée selon que les membres du groupe ont ou non proclamé publiquement leurs décisions individuelles à la fin de la discussion. Les prises de risque de groupes plus nombreux ont été accompagnées d'auto-estimations plus élevées apportées par des membres du gronine sur un certain nombre d'échelles de polarité. En discutant les conclusions nous ébauchons une explication concernant les décalages provoqués dans les groupe-c quant à la prise de risque, soulignant les incitations de caractère motivation- ment of Psychology, University of Western Ontario, Res. Bull. 128, Oktober.

Vinokur, A. (1969) Distribution of initial risk levels and group decisions involving risk. J. Pers. soc. Psychol. 13, 207-214.

Vinokur, A. (1971) Cognitive and affective processes influencing risk taking in groups: An expected utility approach. J. Pers. soc. Psychol. 20, 472-486.

Wallach, M. A., and Wing, C. F. Jr. (1968) Is risk a value? J. Pers. soc. Psychol. 9, 101-106.

\section{Zusammenfassung}

Zwölf Vierpersonen-Gruppen, deren Mitglieder in einer Voruntersuchung die Risikoneigung ihrer Peer-Gruppe (Oberschülerinnen) unterschätzt hatten, wurden verglichen mit zwölf Gruppen, bei denen die erwähnte Unterschätzung nicht aufgetreten war. Die Risikoneigung wurde anhand einer Reihe hypothetischer Entscheidungssituationen gemessen, bei denen - in anderen Untersuchungen - nach Gruppendiskussion ein Risikoschub (Erhöhung der Risikoneigung) aufgetreten war. Die Untersuchung ergab, daB die beiden obigen Gruppentypen sich hinsichtlich ihres Ausmaßes an Risikoschub (nach Gruppendiskussion) nicht unterschieden. Damit ist die vielfach geäußerte Behauptung, daß die (für die meisten Vpn typische) Unterschätzung der Risikoneigung der Peer-Gruppe beim Risikoschub eine kausale Rolle spielt, in Frage gestellt. Eine zweite unabhängige Variable - private versus öffentliche Bekundung der Risikoposition durch die Teilnehmerinnen am Ende der Gruppendiskussion - hatte keinen Effekt. Weiter ergab sich, dab tie Mitglieder von Gruppen, die einen stärkeren Risikoschub zeigten, sich auf einer Reihe von Polaritätsskalen höher einschätzten. Auf der Grundlage der hier werierten und anderer neuerer Forschungsergebnisse wird ein Er- 
nel et informationnel apportées par la discussion du groupe au moyen desquelles les membres du groupe en sont venus à écarter leurs positions précédentes en faveur d'autres plus ambitieuses. klärungsansatz für gruppen-induzierte Änderungen der Risikoneigung vorgescblagen. Betont werden darin die Motivations- und Informations-Aspekte der Gruppendiskussion, durch welche die Gruppenmitglieder dazu gebracht werden, ihre ursprünglichen zugunsten hochstrebenderer Positionen aufzugeben.

\section{Резюме}

Двенадцать групп испытуемых, проявляющих типичную недооценку способности своих товарищей по іруппе принять решение, связанное с риском, сравнивались с другими двенадцатью группами испытуемых, которые в этом отношении слегка переоценивали своих товарищей по группе. (Bсе испытуемые женщины; в каждой группе — четверо испытуемых.) Уровень риска измерялся путем ответов.на сериғо гипотетических ситуаций принятия решения, которые, как это известно из предыдущих исследований, вызывают сдвиг в сторону большего риска. Оказалось, что эти два типа групп не различаются по величине сдвига в сторону рнска (происходящего после группового обсуждения); эти данные ставят под сомнение широко распространенное представление о значении неоценки товарицей по группе для изменения уровня риска. Кроме того, сдвиг в сторону риска оказался независящим от того, объявляли или не объявляли члены группы о своем личном решения в конце обсуждения. Больший групповой сдвиг в сторону риска сопровождался более высокими самооценками членов группы по ряду полярных шкал. Рассматривая эти данщые, мы предлагаем такое объяснение зизванных сдвигов в гринятии рискованных решений, которое подчеркивает миинационные и информационные побуждения, обусловленные групповым обсуждением, вследствие которого члены группы начинают отказываться от свочх прежних решений в пользу решений, соответствуюших более высоким запрісам. 